\title{
Urban Homegarden for Woody Species Conservation and Carbon Sequestration: The Case of Jimma City, Southwest Ethiopia
}

\author{
Kassahun Mulatu \\ Department of Natural Resource Management, College of Agriculture And Natural Resource, Mizan Tepi \\ university, P. O. Box: 260; Mizan Teferi, Ethiopia
}

\begin{abstract}
Homegardens in urban are found to be an important refuge for native biodiversity and provide huge contribution for climate change mitigation. The study was undertaken to investigate potential of homegarden in conservation of woody species and carbon sequestration in Jimma City. A complete listing of woody species within 138 homegardens and 39 sample plot size $10 \mathrm{~m} \times 10 \mathrm{~m}\left(100 \mathrm{~m}^{2}\right)$ were surveyed. Diameter at breast) height and the height of the tree were measured. Shannon diversity and Jaccard coefficient of similarity index were used to determine the species composition. Allometric equation was used to estimate aboveground carbon stocks of woody species. A total of 40 woody species ( 36 in homegarden and 22 in government institution) belonging to 24 families were recorded. Very significantly higher $(\mathrm{P}<0.001)$ species richness and diversity were observed in homegardens. But no significant difference was observed $(\mathrm{p}>0.5)$ among homegardens in three kebeles. Jaccard coefficient of similarity index $(47.5 \%)$ showed low similarity in woody composition between two systems. About 2,877.13 $\mathrm{Mgha}^{-1}\left(884.2 \mathrm{Mgha}^{-1}\right.$ in homegarden $\& 1,992.95 \mathrm{Mgha}^{-1}$ in government institution) carbon of about $319.57 \mathrm{Mg}$ of $\mathrm{CO}_{2}$ equivalents were measured. Very highly significant $(\mathrm{p}<0.001)$ and non-significant difference $(p>0.05)$ in carbon storage were observed between systems and among homegardens respectively. The result reveled homegardens in Jimma city have good potential for biodiversity conservation and climate change mitigation. Hence, responsible bodies need to consider the role of homegarden in maintaining native biodiversity and climate change mitigation in urban development planning.
\end{abstract}

Keywords: Biodiversity conservation, government institution compound, carbon stock, climate change mitigation. DOI: $10.7176 / \mathrm{JNSR} / 9-13-02$

Publication date:July $31^{\text {st }} 2019$

\section{Introduction}

Vegetation in urban landscape including agroforestry have played important role in maintaining the well-being of inhabitants through provision of numerous ecosystem services necessary for the human development. They are important for role playing in intrinsic value, natural and cultural heritage, sense of place, climate amelioration, noise amelioration, pollution filtration, water-sensitive urban design and human health and wellbeing (McDonnell and Hahs, 2012). Urban vegetation area can provide high impact ecosystem services (Dearborn and Kark, 2009) such as climate-change mitigation through increasing carbon storage and uptake, providing more shade and cooling thereby reducing overall energy consumption, and significantly reducing the urban heat island effect (Secretariat of the Convention on Biological Diversity, 2012). They can also play important part in maintaining biodiversity that are under risk of disappearance in the natural habitat by offering a unique opportunity for preservation (Mengistu and Alemayehu, 2017).

However, urbanization transforms the local biophysical environment especially forestland (Sejati et al., 2018) and accelerates biodiversity loss (Akinnifesi et al., 2010). The removal of trees and breakdown of traditional agroforestry systems (Thaman et al., 2006) associated with urbanization attributed to greatest local extinction rates and frequently eliminates the large majority of native species (Mckinney, 2002).

The rapid urbanization in Ethiopia, which has increased from 3.7\% in 1984 to $19 \%$ in 2014 and predicted to climb up to $38 \%$ in 2050, have expanded their territory into the immediate hinterlands (Mengistu and Alemayehu, 2017) such as forest, wetlands and other ecosystem. Besides, urban forests in Ethiopia have encountered various problems such as encroachment, illegal cuttings, low legal enforcement and improper tree selection (Shikur, 2012). Enormous observable environmental changes including forest cover change, which could have potential impact on ecological functioning and environmental sustainability, were reported in and around Jimma City due to urban expansion (Chalachew et al., 2015). Such loss of forest resources contributed substantial increase in concentration of $\mathrm{CO}_{2}$ in the earth's atmosphere (IPCC, 2007; Nair et al., 2010; Axel et al., 2011). Nevertheless agroforestry such a homegardens in urban area can play important role in biodiversity conservation and mitigation of $\mathrm{CO}_{2}$. Homegardens, as the most elaborate manmade, tree-crop-animal associations, resembling a natural ecosystem and offer valuable ecosystem functions (Kumar and Tripathi, 2017). They maintain the biological diversity of native and exotic as well as managed or wild species (Kunhamu, 2013) and hold a large potential for climate change mitigation through storing carbon (Verchot, 2007; Nair et al., 2009; Mattsson et al., 2015).

Studies reported the potential of agroforestry in conservation biodiversity and storage of carbon. For instance, Mengistu and Alemayehu (2017) reported that various species of higher plant species of various use in Bahir Dar 
City, Ethiopia. On other hand, Kumar (2011) and Bajigo et al. (2015) reported about 24.32 $\mathrm{Mg} \mathrm{C}^{-1}$ and 86.4 $\mathrm{Mg} \mathrm{C} \mathrm{ha-1} \mathrm{in} \mathrm{rural} \mathrm{homegardens} \mathrm{of} \mathrm{central} \mathrm{Kerala,} \mathrm{India} \mathrm{and} \mathrm{Ethiopia.} \mathrm{However,} \mathrm{the} \mathrm{research} \mathrm{report} \mathrm{on} \mathrm{role} \mathrm{of}$ urban homegarden for carbon sequestration is scarce in general. Because of this and other reason, the potential of agroforestry especially understanding for $\mathrm{C}$ sequestration and biomass production is limited (Jose and Bardhan, 2012) or marginalized in urban area (Tellström, 2014). Other scholar (e.g. Thaman et al., 2006; Kunhamu, 2013) also stated the limited understanding of agroforestry from ecosystem service perspective. The same is true in Ethiopia, where climate change mitigation roles of agroforestry remain largely unknown (Seta and Demissew, 2017). Such lack of awareness due to lack of scientific information has triggered the loss of biodiversity and increase in $\mathrm{CO}_{2}$ in general and urban area in specific.

But native and exotic woody species in homegardens and compounds of different government and nongovernmental institution, and rode sides of Jimma City need to be studied and their essential role in mitigation of $\mathrm{CO}_{2}$ and thereof mitigating climate change should be documented. Thus, studies that evaluate the environmental role of urban homegarden of Ethiopia in general and Jimma City in particular are crucial for improving the understanding of the role of urban forests and agroforestry in ecosystem services especially biodiversity conservation and climate change mitigation. This is apparent to have decision makers and city planners prioritize their existence for climate change mitigation and adaptation options. Thus, this study was aimed to evaluate the potential of homegarden for conservation of woody species and carbon sequestration in selected kebeles of Jimma City, southwest Ethiopia.

\section{Materials and Methods}

\subsection{Description of the study area}

Jimma City is located in Jimma Zone of Oromia Regional State (Figure 1). It is located at $335 \mathrm{~km}$ southwest of Addis Ababa, federal capital of Ethiopia. Geographically, it is located in latitude $7^{\circ} 40^{\prime} \mathrm{N}$ to $7.667^{\circ} \mathrm{N}$ and longitude of $36^{\circ} 50^{\prime} \mathrm{E}$ to $36.833^{\circ} \mathrm{E}$. The elevation ranges from 1700 to over $2000 \mathrm{~m}$.a.s.l. The City is characterized by flat to gently sloping topography and undulating landscape. The main economic activities in the City are commerce and small scale manufacturing enterprises (World Bank, 2011). The mean emperature of the City is ranges from $12^{\circ} \mathrm{C}$ to $29^{\circ} \mathrm{C}$ with the mean daily temperature of $19.5^{\circ} \mathrm{C}$. The rainfall is unimodal distribution with mean annual rainfall of around $1500 \mathrm{~mm}$ and annual potential evaporation is about $1465 \mathrm{~mm}$. Geologically, the area consists of various Tertiary Volcanic and younger Quaternary Sediments with reddish brown residual soils and alluvial soils of brownish gray and grayish white clay soils. Homegardens, riparian forests, green areas, trees in compounds of institutions, remnants of natural forest are major vegetation characterize Jimma City. Though, the original vegetation of the Jimma area has been totally modified by human activities and currently it is covered by some remnant trees, bushes and shrubs (World Bank, 2011).

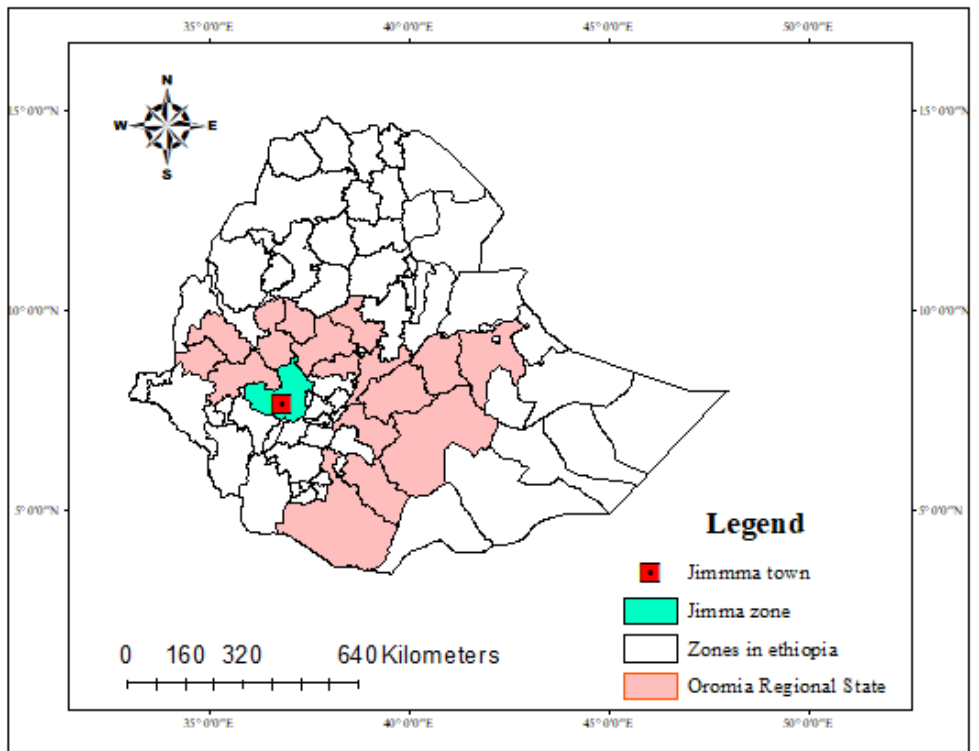

Figure 1 Map of the study area

\subsection{Research methods}

2.2.1 Sampling techniques and data collection methods

Reconnaissance survey was conducted to collect basic information and understand biophysical setting of the study area for determination of the sampling design. Three representative kebeles (the smallest administrative unit) were 
selected purposively based on presence of homegarden agroforestry system. In each selected kebele, three villages were selected randomly and investigated. After households who have woody species in their homegardens were identified, homegarden of household heads were randomly selected as sampling plots for biomass assessment. A total of 138 (46 from each kebele) households' homegardens were investigated. The total numbers of households were determined using the following formula as the total numbers of the population were unknown (Cochran, 1977):

$$
n=\frac{Z^{2} p q}{e^{2}}
$$

Where: $n=$ size of sample, $p=0.1$ (proportion of population to be included in the sample i.e. $10 \%$ ); $q=1-P$ i.e. $(0.9)$; $\mathrm{e}=0.05$ ( $5 \%$ standard error considered.), and $z=1.96$ (as per table of area under normal curve for the given confidence level of $95 \%$ ).

Eight governmental institutions were also selected purposively based on based on the presence of woody species in their compounds with exception of security related institution were investigated. In government institution, a total of 39 sample plots placed at most five sample plots of $10 \times 10 \mathrm{~m}\left(100 \mathrm{~m}^{2}\right)$ at each corner and one at the center were used. Furthermore, no sample plots were used for homegarden rather complete measure of woody species was carried out (Motuma et al., 2008).

Therefore, all tree species in each sample plot/homegarden were recorded and diameters at breast height (DBH, $1.3 \mathrm{~m}$ ) were measured for all woody species $\geq 5 \mathrm{~cm}$ except for coffee (MacDicken, 1997). The diameter of coffee shrubs was measured at $15 \mathrm{~cm}$ aboveground (Segura et al, 2006). Only woody species with DBH $\geq 5 \mathrm{~cm}$ were taken for determining above ground biomass (Sales, 2005; Motuma et al., 2008). The diameter of tree was measured following standard procedure provided by FAO (2012) using calipers and diameter tapes. In addition, at every sampling point, number of individuals per plot and the height was measured and recorded. Tree/woody species with height more than $2.5 \mathrm{~m}$ was measured by using measuring suunto clinometer while woody species with height $\leq 2.5 \mathrm{~m}$ was measured by graduated stick. Furthermore, the area of homegarden and GPS readings of each sampling plots/households homegardens were measured and recoded respectively.

2.2.2 Data analysis

2.2.2.1 Analysis of woody species composition

Woody species composition and structure were determined through quantitative analysis such as diversity indexes and important value index (IVI) respectively. Diversity index such as Shannon diversity index, evenness and Jaccard coefficient of similarity index were used to determine the species composition. Shannon diversity index (H') was used to determine species diversity using the following formula:

$$
H^{\prime}=\sum_{i=1}^{s} P_{i} \ln P_{i}
$$

Where $\mathrm{H}^{\prime}$ is Shannon diversity index, $p_{i}$ is proportion of individuals found in the $i^{\text {th }}$ species and $\mathrm{S}=$ number of species in community.

Evenness (Shannon equitability) index $(E)$ was calculated as:

$$
E=\frac{H^{\prime}}{\ln S}
$$

Jaccard coefficient of similarity index (JCS) was used to assess the similarity of plant species composition between homegarden and government institutions using the formula (Kent and Coker, 1992):

$$
\mathrm{JCS}=\frac{C}{A+B+C} \times 100
$$

Where: $\mathrm{C}=$ the number of species in common (homegarden and government institutions compound), $\mathrm{A}=$ the number of unique species in homegarden, $\mathrm{B}=$ the number of unique species in government institution compound. The Jaccard coefficient of similarity index value was converted to percentage to show the percentage similarity between two systems.

The important value indexes (IVI), which is the sum of relative frequency (RF), relative density (RD), and relative dominance (RDO), were analyzed using the formula (Mueller-Dombois and Ellenberg, 1974; Martin, 1995) as:

$\mathrm{IVI}=\mathrm{RDO}+\mathrm{RF}+\mathrm{RD}$

Where RDO, RF and RD were computed as follows:

Relative Dominance $($ RDO $)=\frac{\text { Dominance of a specie }}{\text { Total dominance of all species }} \times 100$

Dominance (D)of species $=\frac{\text { Total basal area }}{\text { Area sampled }} \times 100 \%$

$B A=\frac{\pi(D B H)^{2}}{40000}$

Where, $\mathrm{BA}=$ basal area $\left(\mathrm{m}^{2}\right) ; \mathrm{DBH}$ is the diameter of trees at breast height $(\mathrm{cm})$ 


$$
\begin{aligned}
& \text { Relative frequency }(\mathrm{RF})=\frac{\text { Frequency of a species }}{\text { Total frequency of all species }} \times 100 \% \\
& \text { Frequency of a species }(\mathrm{F})=\frac{\text { Number of plots with that species }}{\text { Total number of plots }} \times 100 \\
& \text { Relative density (RD) }=\frac{\text { Density of a species }}{\text { Total density of all species }} \times 100 \% \\
& \text { Density (D) }=\frac{\text { Number of indivduals of that species }}{\text { Sample area (ha) }} \times 100
\end{aligned}
$$

\subsubsection{Estimation of carbon stock}

The total carbon focused only on the live wood biomass carbon (above and below ground biomass of live woody species) because of continuous removal dead wood and leaf litter in homegarden agroforestry system. Therefore, sum of the above ground biomass (AGB) and belowground biomass (BGB) was taken as total tree biomass. The AGB carbon stocks were calculated for each tree and aggregated to calculate total AGB carbon stock in each homegarden and tree in governmental institutions. Assessments of AGB were done non-destructively using allometric biomass regression equations. Due to the lack of a standard approach and available allometric equations to estimate AGB for homegarden agroforestry systems in Ethiopia, allometric equations developed by SteffanDewenter et al (2007) for Tropical Agroforestry was used as:

$\ln Y=-3.375+0.948 \times \ln \left(D^{2} \times H\right)$

Where; $\mathrm{Y}=$ aboveground total biomass per tree $(\mathrm{kg}), \mathrm{D}=\mathrm{DBH}(\mathrm{cm})$ and $\mathrm{H}=$ Height $(\mathrm{m})$.

BGB was determined by multiplying AGB by root to shoot ratio of 0.26 (Hangarge et al., 2012; Suryawanshi et al., 2014, Patil, et al., 2016). This is because determining below ground biomass is difficult, expensive and laborious (Brown, 1997) and uncommon in the literature. Therefore, BGB was estimate as:

$B G B=0.26 \times A G B$

Total biomass of a tree was the sum of the above and below ground biomass (Sheikh et al., 2011) as:

Total biomass $=A G B+B G B$

For comparisons on unit area basis, total biomasses were extrapolated to hectare size. Finally, as carbon stock of woody species was calculated based on the association that carbon stock any plant species is $50 \%$ of its biomass (Brown 1997; Pearson et al., 2005). Therefore, biomass carbon stock of a woody species (DBH $\geq 5 \mathrm{~cm})$ was calculated for each woody species and aggregated to calculate total biomass carbon stock for each homegarden and government institutions compound:

Total biomass carbon tree $=$ Total biomass $\times 50 \%$

The total amount of $\mathrm{CO}_{2}$ sequestered $\left(\mathrm{CO}_{2}\right.$ equivalent $\left.\left(\mathrm{CO}_{2 \mathrm{e}}\right)\right)$ by the tree was calculated by multiplying the amount of carbon in the biomass by 3.67 (which is the ratio of the atomic mass of $\mathrm{CO}_{2}$ (44.01) to the atomic mass of carbon (12) (Kauffman and Donato, 2012).

$\mathrm{CO}_{2 \mathrm{e}}=\mathrm{TCS} \times 3.67$

Statistical analysis

SPSS (Statistical package for social science, version 20.0) and PAST (PAleontological STatistics Version 3.23) software were used to summarizes and analyze data. Descriptive statistics such as total, mean and standard deviation were used to summarize total biomass and carbon stock. Two (independent) sample $t$-tests was use to show the differences in biodiversity and total carbon stock between the homegardens and in government institutions while one-way ANOVA was used to test the difference in biodiversity and total carbon stock between homegardens in three kebeles. A significant difference in mean values for carbon stock was tested by least significance difference at $\mathrm{p}<0.05$.

\section{Result and Discussion}

\subsection{Floristic composition and structure}

3.1.1 Floristic composition

A total of 40 woody species belonging to 24 families were recorded from homegarden and government institution compound. From the total species recorded, 36 species belongs 23 families and 22 species belongs to 13 families were recorded from homegarden and governmental institution respectively (Table 1). 
Table 1. Woody species in homegarden and government institutions and their origin

\begin{tabular}{|c|c|c|c|c|}
\hline \multirow[t]{2}{*}{ Scientific name } & \multirow[t]{2}{*}{ Family Name } & \multicolumn{2}{|c|}{ Presence/absence } & \multirow[t]{2}{*}{ Origin } \\
\hline & & Gov. inst. & $\mathrm{HG}$ & \\
\hline Acacia bussei & Fabaceae & + & + & $\mathrm{N}$ \\
\hline Albizia gummifera & Fabaceae & + & + & $\mathrm{N}$ \\
\hline Annona senegalensis & Annonaceae & + & + & $\mathrm{N}$ \\
\hline Annona squamosa & Annonaceae & + & + & $\mathrm{E}$ \\
\hline Casuarina equisetifolia & Casuarinaceae & + & + & $\mathrm{E}$ \\
\hline Coffee arabica & Rubiaceae & + & + & $\mathrm{N}$ \\
\hline Cordia Africana & Boraginaceae & + & + & $\mathrm{N}$ \\
\hline Croton macrostachyus & Euphorbiaceae & + & + & $\mathrm{N}$ \\
\hline Dracaena steudneri & Dracaenaceae & + & + & $\mathrm{N}$ \\
\hline Erythrina abyssinica & Fabaceae & + & + & $\mathrm{N}$ \\
\hline Eucalyptus camaldulensis & Myrtaceae & + & + & $\mathrm{E}$ \\
\hline Euphorbia abyssinica & Euphorbiaceae & + & + & $\mathrm{N}$ \\
\hline Grevillea robusta & Proteaceae & + & + & $\mathrm{E}$ \\
\hline Juniperus procera & Cupressaceae & + & + & $\mathrm{E}$ \\
\hline Mangifera indica & Anacardiaceae & + & + & $\mathrm{E}$ \\
\hline Melia azedarach & Meliaceae & + & + & $\mathrm{E}$ \\
\hline Persea americana & Lauraceae & + & + & $\mathrm{E}$ \\
\hline Psidium guajava & Myrtaceae & + & + & $\mathrm{N}$ \\
\hline Sesbania sesban & Fabaceae & + & + & $\mathrm{N}$ \\
\hline Albizia schimperiana & Ebenaceae & - & + & $\mathrm{N}$ \\
\hline Bridelia micrantha & Euphorbiaceae & - & + & $\mathrm{N}$ \\
\hline Callistemon citrinus(Curt) Skeels & Myrtaceae & - & + & $\mathrm{N}$ \\
\hline Casimiroa edulis & Rutaceae & - & + & $\mathrm{E}$ \\
\hline Catha edulis & Celastraceae & - & + & $\mathrm{N}$ \\
\hline Citrus sinensis & Rutaceae & - & + & $\mathrm{E}$ \\
\hline Combretum aculeatum & Combretaceae & - & + & $\mathrm{N}$ \\
\hline Dovyalis abyssinica & Flacourtiaceae & - & + & $\mathrm{N}$ \\
\hline Ekebergia capensis & Meliaceae & - & + & $\mathrm{N}$ \\
\hline Millettia ferruginea & Fabaceae & - & + & $\mathrm{E}$ \\
\hline Moringa oleifera & Moringaceae & - & + & $\mathrm{E}$ \\
\hline Olea europaea subsp. & Oleaceae & - & + & $\mathrm{N}$ \\
\hline Prunus africana & Rosaceae & - & + & $\mathrm{N}$ \\
\hline Sapium ellipticum & Euphorbiaceae & - & + & $\mathrm{N}$ \\
\hline Schinus molle & Anacardiaceae & - & + & $?$ \\
\hline Spathodea campanulata & Bignoniaceae & - & + & $\mathrm{N}$ \\
\hline Vernonia amygdalina & Asteraceae & - & + & $\mathrm{N}$ \\
\hline Vernonia mycrocephala & Asteraceae & - & - & $\mathrm{N}$ \\
\hline Acacia tortilis & Fabaceae & + & - & $\mathrm{N}$ \\
\hline Pithecellobium duice & Fabaceae & + & - & $\mathrm{E}$ \\
\hline Ficus vasta Forssk & Moraceae & + & - & $\mathrm{N}$ \\
\hline
\end{tabular}

Note: $\mathrm{HG}=$ homegarden, Gov inst. = governmental institution $+=$ presence,$-=$ absence, $\mathrm{N}=$ native, $\mathrm{E}=$ exotic

About $62.5 \%$ (25) species native including endemic (e.g. Millettia ferruginea) was recorded in homegarden indicating homegardens including urban area are important refuges for biodiversity reserves. Eight families (Figure 2) such as Fabaceae, Euphorbiaceae, Myrtaceae, Rutaceae, Anacardiaceae, Annonaceae, Asteraceae and Meliaceae consist of two and above species. The family Fabaceae (14.3\% or 5 species) and Euphorbiaceae $(11.43 \%$ or 4 species) are the families with highest species in homegarden and while Fabaceae was the highest (28.6\% or 6 species) in governmental institution. The result revealed that the numbers of species recorded in homegardens were higher than reported by Mengistu and Asfaw (2015), which was 15 in Dallo Mena District, South-East Ethiopia. 


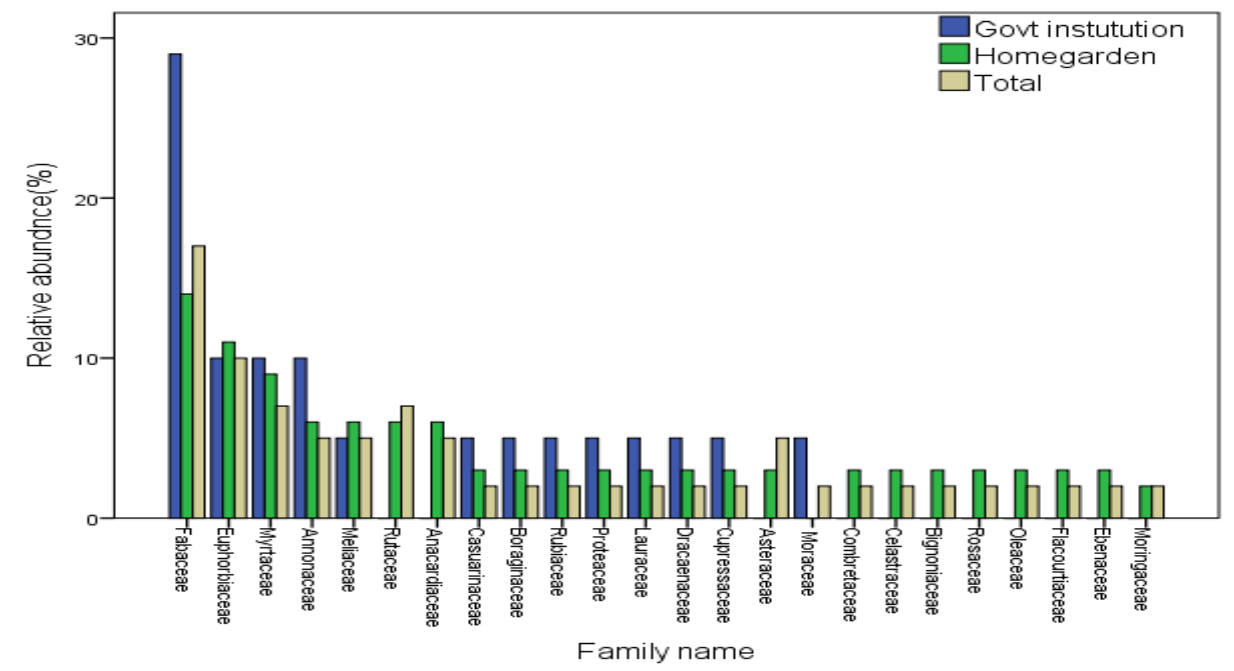

Figure 2. Relative abundances of families in homegarden and governmental institution

3.1.2 Species diversity, richness and equitability

The overall diversity index (species richness, $\mathrm{H}^{\prime}$ and $\mathrm{E}$ ) of the entire homegarden and governmental institution (Table 2) revealed homegardens were higher $\left(H^{\prime}=2.34\right)$ in species diversity than governmental institutions compound $\left(\mathrm{H}^{\prime}=2.17\right)$. At individual homegarden and/or plot level, homegardens were highly significantly richer $(\mathrm{p}<0.001)$ and diverse than government institution compound. However, density of woody species (individual/ha) was very highly significantly higher $(\mathrm{p}<0.001)$ in governmental institution than in homegarden. Based on Cavalcanti and Larrazábal (2004), the diversity index (H') showed medium diversity and low diversity at site and plot level as it was between 2.0 and 3.0(medium) and between 1.0 and 2.0(low) respectively. The evenness index (E) also revealed that the distribution of species within homegardens were low which indicated there is the dominance of one or few species in the community. Jaccard coefficient of similarity index (JCS) $47.5 \%$, which indicate there was low (below average) similarity in composition of woody species between homegarden and government institution compound.

Table 2. Diversity indices for species from homegarden and government institution

\begin{tabular}{|c|c|c|c|c|c|}
\hline \multirow[t]{2}{*}{ Diversity indices } & & \multirow{2}{*}{ Homegarden } & Govt. inst. & \multicolumn{2}{|c|}{ Test statistics } \\
\hline & & & Mean \pm Std. Dev. & t-test & p-value \\
\hline \multirow[t]{2}{*}{ Species richness } & system level & 36 & 22 & & \\
\hline & Plot level & $7.43 \pm 2.10$ & $4.71 \pm 1.27$ & 7.05 & $0.0001 * * *$ \\
\hline Shannon & Site level & 2.34 & 2.17 & & \\
\hline diversity(H') & Plot level & $1.54 \pm 0.32$ & $1.14 \pm 0.29$ & 5.24 & $0.0001 * * *$ \\
\hline \multirow[t]{2}{*}{ Evenness(E) } & Site level & 0.38 & 0.57 & & \\
\hline & Plot level & $0.45 \pm 0.12$ & $0.41 \pm 0.098$ & 1.94 & $0.0573^{\mathrm{ns}}$ \\
\hline Density & Plot level & $353.41 \pm 223.69$ & $1287 \pm 617.35$ & -12.014 & $0.0001 * * *$ \\
\hline JCS index & \multicolumn{5}{|c|}{$47.5 \%$} \\
\hline
\end{tabular}

Note: $* * *$ very highly significant at $\mathrm{p}<0.001,{ }^{\mathrm{ns}}=$ non-significant.

However, all diversity indices and density (individual per ha) were not significant different ( $\mathrm{p}>0.05$ ) among homegarden in all kebeles (Figure 3). This might be due to more or less similar landholding size, similar farming system and socioeconomic dependence on plant species. 

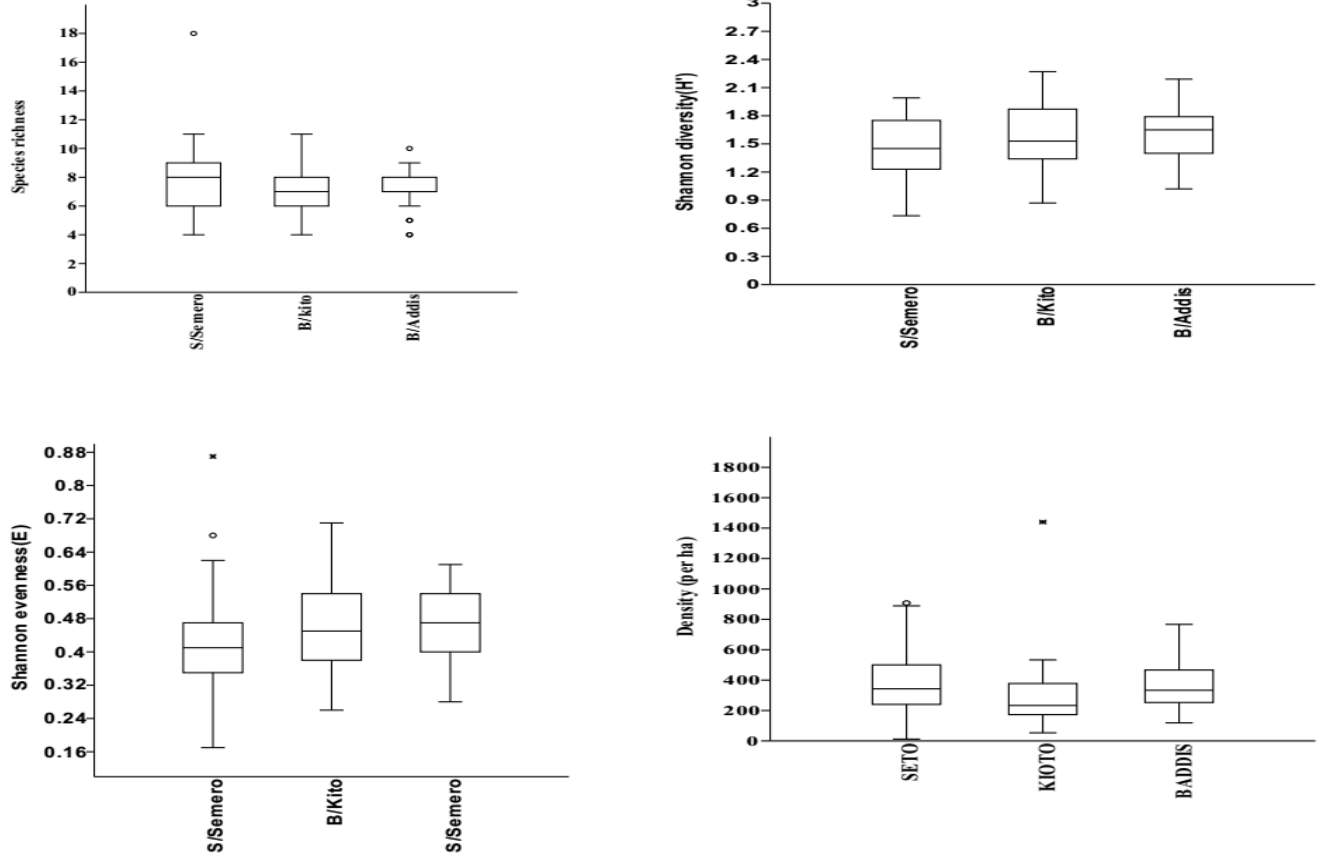

Figure 3. Boxplot comparison of diversity indices and density species in homegarden of three kebeles 3.1.3 Vegetation structure analysis

Relative frequency, relative density, relative dominance and importance value index (IVI) are important parameters commonly used to investigate the structure of vegetation. In homegarden (Table 2), Ekebergia capensis (12.53\%), Persea Americana (8.14\%), Mangifera indica (7.69\%), Croton macrostach'yus (6.47\%) and Grevillea robusta $(5.88 \%)$ made the largest contribution to the basal area and represent the most ecologically important woody species in homegarden. The result also revealed that Coffee arebica(11.71\%), Mangifera indica (11.55\%), Persea Americana (9.27\%), Juniperus procera(7\%), Grevillea robusta (6.83\%), Psidium guajava(6.67\%) and Cordia Africana (6.5\%) scored the highest relative frequency, that reflects their pattern of distribution and an approximate indication of the heterogeneity of a stand (Zegeye et al. 2005; Melese and Ayele, 2016). Similarly, Coffee arebica (42.17\%), Mangifera indica (22.34\%), Persea Americana (17.71\%), Citrus sinensis (15.55\%), Grevillea robusta (15.12\%), Ekebergia capensis (14.77\%), Juniperus procera (13.88\%), Croton macrostachyus $(12.76 \%)$, Cordia Africana (12.75\%), Psidium guajava (10.17\%) and Dracaena steudner(10.1\%) contributed a total of $62.18 \%$ of the total IVIs, indicating that they are the most ecologically important woody species in homegarden system. Furthermore, these trees might have a multipurpose role both in terms of ecological and economic values for the local communities. Similar trends were observed by Mengistul and Alemayehu(2017) in Bahir Dar City, Ethiopia where fruit woody species such as Mangifera indica(20.3\%), Psidium guajava(134.\%) and Persea Americana (11.6\%) were the most abundant perennial plant species. On other hand, non-fruit woody species such as Juniperus procera, Eucalyptus camaldulensis, Erythrina abyssinica

Croton macrostachyus and Grevillea robusta all together accounted for about $63.03 \%$ of IVI value in governmental institutions. The difference in species based IVI between homegarden and government institution could be the difference in socioeconomic and ecological significance of the species for household and the government institution.

Table 3. Species with highest IVI in homegarden and government institution compound

\begin{tabular}{lllr}
\hline Species in homegarden & IVI & Species in government institution compound & IVI \\
\hline Coffee arebica & 42.17 & Juniperus procera & 35.69 \\
Mangifera indica L & 22.34 & Eucalyptus camaldulensis & 27.489 \\
Persea americana & 17.71 & Erythrina abyssinica & 23.704 \\
Citrus sinensis & 15.55 & Croton macrostachyus & 22.934 \\
Grevillea robusta & 15.12 & Grevillea robusta & 20.934 \\
Ekebergia capensis & 14.77 & Ficus vasta Forssk & 20.09 \\
Juniperus procera & 13.88 & Melia azedarach & 19.312 \\
Croton macrostachyus & 12.76 & Cordia Africana & 18.89 \\
Cordia Africana & 12.75 & Persea americana & 17.973 \\
Psidium guajava & 10.17 & Psidium guajava & 13.754 \\
Dracaena steudner & 10.05 & Sesbania sesban & 12.373 \\
Percent & $62.18 \%$ & Percent & $77.73 \%$ \\
\hline
\end{tabular}




\subsection{Estimated carbon storage}

Biomass density indicates the potential amount of $\mathrm{CO}_{2}$ that can be released to the atmosphere when vegetation is burned or cleared. The total amount carbon stored due to the presence of wood biomass was estimated to $87.08 \mathrm{Mg}$ $\left(2,877.13 \mathrm{Mgha}^{-1}\right)$ of which homegarden agroforestry contributed about $64.35 \mathrm{Mg}\left(884.18 \mathrm{Mgha}^{-1}\right)$ and $22.73 \mathrm{Mg}$ $(1,992.95 \mathrm{Mg} / \mathrm{ha})$ of biomass carbon from government institution. Thus, a total of about $319.57 \mathrm{Mg}$ of $\mathrm{CO}_{2}$ equivalents were estimated to sequestered from both homegarden and government institution. From this homegarden agroforestry sequestered about $236.145 \mathrm{Mg}(73.89 \%)$ of $\mathrm{CO}_{2}$ equivalent from atmosphere.

On area basis, the result revealed that total biomass carbon ranges from $0.34 \mathrm{Mgha}^{-1}$ to $22.39 \mathrm{Mgha}^{-1}$ with mean value of $22.48 \mathrm{Mgha}^{-1}$ was stored in woody biomass of both institutions. The result revealed that that carbon stored in governmental institution $\left(62.28 \mathrm{Mgha}^{-1}\right)$ was significantly higher $(p<0.001)$ than that of homegarden (9.21 $\left.\mathrm{Mgha}^{-1}\right)$ (Figure 4).
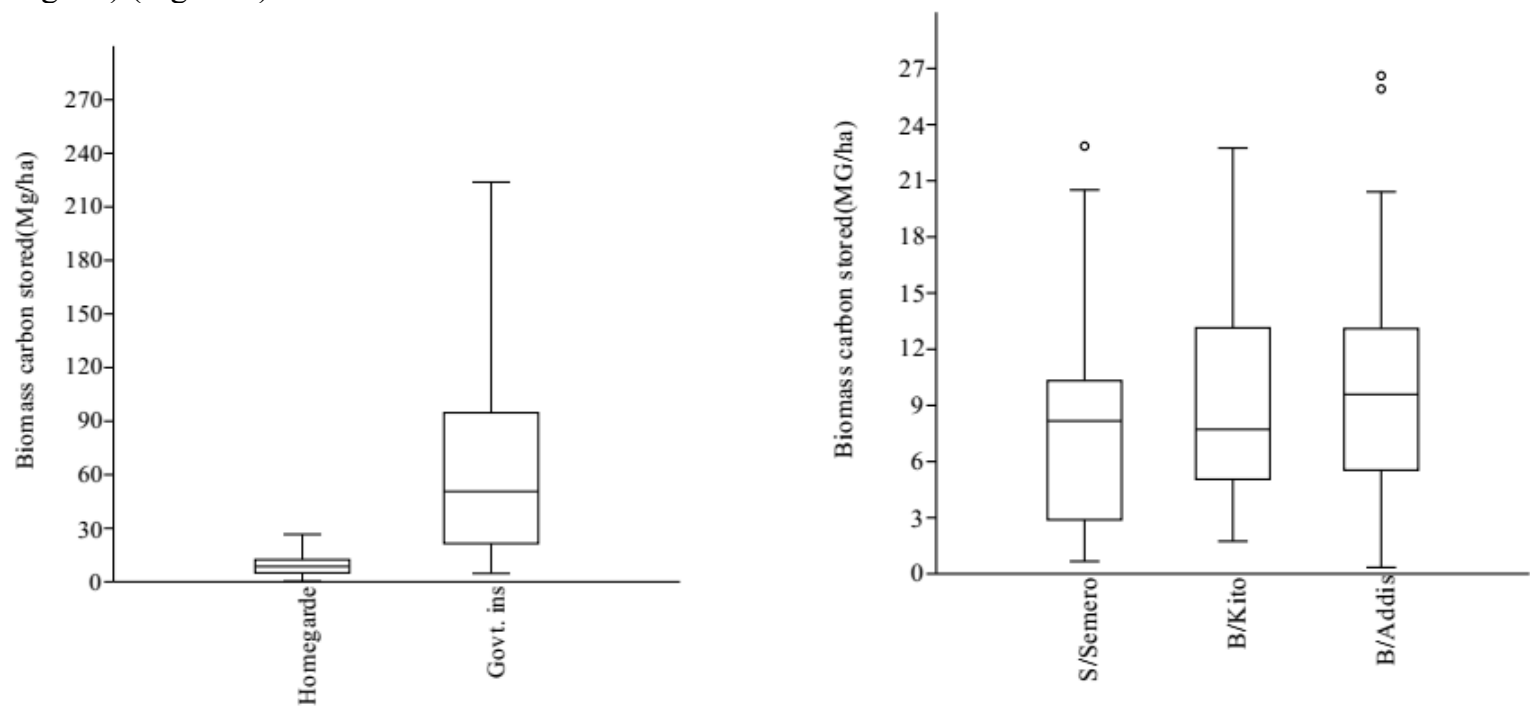

Figure 4. Boxplot comparison of carbon stored in homegarden and government institution compound (left) and across homegarden in three kebeles (right).

The reason for higher amount of carbon storage in governmental institutions could be due to the differences in composition of tree, density and type of management practices. As it was reported depicted in Table 2 and Table 4, there was highly significant difference in density between two system and strong correlation between density and amount of carbon stored( $\left.\mathrm{r}=0.59^{* *}\right)$. As the result revealed species with lower basal area (DBH) such as Coffee arebica and other woody species were dominant in homegarden (Table 2) whereas large tree like Juniperus procera, Eucalyptus camaldulensis, Erythrina abyssinica, etc. large basal area are found in government institutions contribute much carbon storage. Different scholars also revealed that species composition (Montagnini and Nair, 2004; Henry et al., 2009) and woody species volume (Perez and Kanninen, 2003; Henry et al., 2009; Guiabao, 2016: Seta and Demissew, 2017) have direct impact on above ground biomass produced and in turn on total carbon stored in woody species. Besides, woody species in governmental institutional compounds are woodlot type distribution with higher density than homegarden. Henry et al (2009) and Bajigo et al. (2015) confirmed this that woodlots stored higher amount of carbon than homegarden agroforestry because of high basal and stand density. Besides, the total biomass carbon of the study homegarden was higher than that reported by Waktole(2019) in homegarden $(5.54 \mathrm{Mg} / \mathrm{ha})$ and pastureland $(3.47 \mathrm{Mg} / \mathrm{ha})$ of Sokoru District, Jimma Zone. Moreover, it was also higher than that reported in Gununo Watershed, Wolayitta Zone, Ethiopia (8.29 $\mathrm{MgCha}^{-1}$ ) (Bajigo et al., 2015). The overall above ground carbon (AGC) stored in study homegarden (17.84 $\left.\mathrm{Mgha}^{-1}\right)$ was higher than that stored in homegardens in a dry zone area of Moneragala district, Sri Lanka, which was $12.7 \mathrm{Mg} \mathrm{C} \mathrm{ha-1} \mathrm{(Mattsson} \mathrm{et} \mathrm{al.,}$ 2015) and reported by Roshetko et al. (2002) in Indonesia which ranges from 55.8 to $162.7 \mathrm{Mg} \mathrm{C} \mathrm{ha}^{-1}$. But the amount of biomass carbon stock from government institutions $(124.56 \mathrm{Mg} / \mathrm{ha})$ were less than but comparable to that reported by Tsegaye(2015) from Urban Public Parks in in Addis Ababa which was reported as $142.498 \mathrm{Mg} / \mathrm{ha}$ and by Yilma (2016) from church forests in Addis Ababa, which was $147.5 \mathrm{Mg} / \mathrm{ha}$. 
Table 4. Correlation between biodiversity index and biomass carbon stock

\begin{tabular}{l|lllll}
\hline & Density & Carbon $\left(\mathrm{Mgha}^{-1}\right)$ & Spp. richness & H' & E \\
\hline Density & 1 & $\mathbf{0 . 5 8 8}^{* *}$ & $\mathbf{- 0 . 2 9 4 ^ { * * }}$ & $\mathbf{- 0 . 2 8 1}^{* *}$ & 0.04 \\
Carbon $\left(\mathrm{Mgha}^{-1}\right)$ & & 1 & -0.143 & -0.151 & 0.028 \\
Spp. richness & & & 1 & $\mathbf{0 . 4 8 1}^{* *}$ & $\mathbf{0 . 3 0 6}^{* *}$ \\
H' $^{\prime *}$ & & & & 1 & $\mathbf{0 . 4 8 7}^{* *}$ \\
E & & & & 1 \\
\hline
\end{tabular}

**. Correlation is significant at the 0.01 level.

The major reason difference in amount of carbon in study area and other area could be attributed to variation in composition and structure tree and woody species, type of tree management practices. Households in all kebeles mostly pruned and cut trees at some height above ground to reduce the risks associated with falling of tree on their house due to wind, commands from Ethiopian electric power corporation to reduce electric contact and to control the effect of ape disturbance around the home. Such management practices have direct effect on total biomass produced (Mattsson et al., 2015) and carbon stored as it reduce the amount of biomass above cut directly. In addition, high variability in carbon estimate report could be difference in climatic conditions of research area (Mattsson et al., 2015)and variation in ages of agroforestry (Yilma, 2016) and variation in methodologies used to estimate carbon in woody biomass(Atangana et al., 2014).

The result showed no significant difference in carbon stored (Bossa-Addis $=10.73 \pm 12.21$, Bossa-kittoo $=$ $12.59 \pm 18.83$ and Seto-Smero $=10.69 \pm 7.12)$ between three study kebeles both at kebele level $(F=2.2, p=0.12)$ and homegarden level $(\mathrm{F}=0.23, \mathrm{p}=0.82)$. This could be due to similar or non-significant in species composition or diversity, density and tree management practices in all kebeles. According to Mattsson et al. (2015), carbon estimates are reflection of the differences in tree density, tree diversity and management practices between individual homegardens.

Among woody species (37) inventoried for carbon estimation (DBH $\geq 5 \mathrm{~cm}) 13$ species (Figure 5) together accounted for about $96.23 \%$ of total carbon produced. Among these, Juniperus procera (22\%), Eucalyptus spp. $(14 \%)$, Cordia africana $(12.3 \%)$ and Persea americana $(11.2 \%)$ are the major contributors. This is contrast to the results reported by Seta and Demissew (2017) where Albizia trees contributed 33\% of above ground carbon (AGC) stock while Cordia africana contributed about $37 \%$ of the standing AGC stock in rural agroforestry in Wenago District, Ethiopia where such species are retained as shed tree for coffee. But in this study Albiza specie (both Albizia gummifera and Albizia schimperiana) accounted for only $0.55 \%$ of carbon stored in homegarden system.

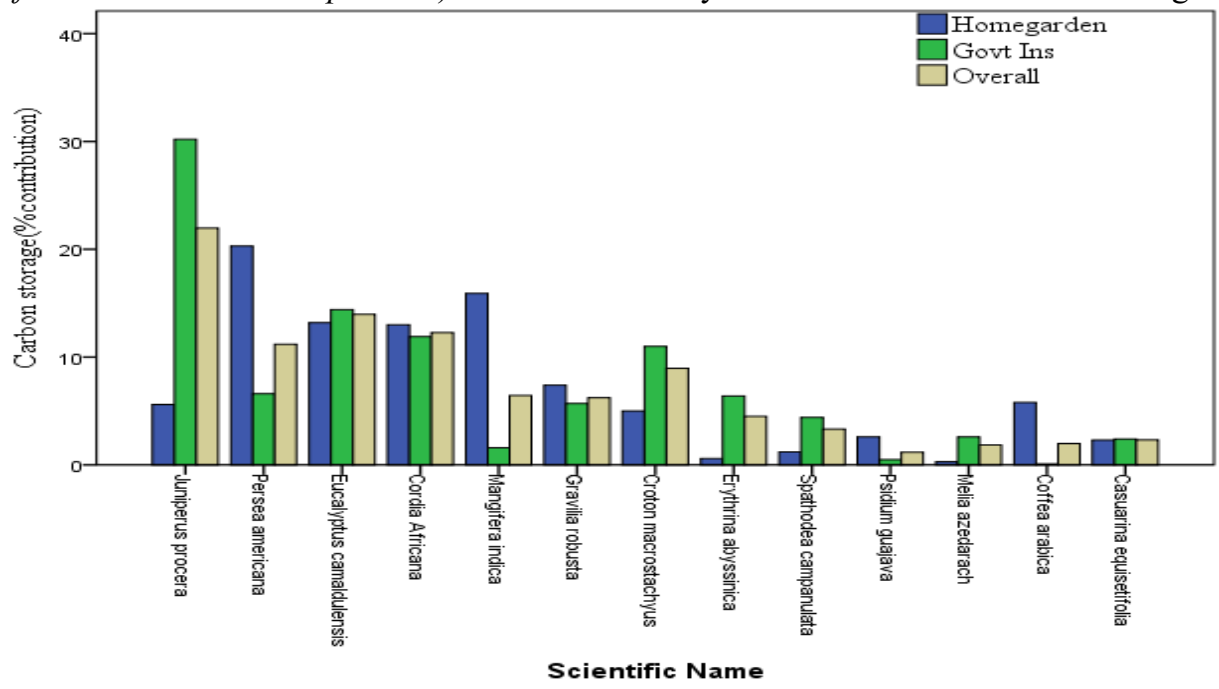

Figure 5. Species contribution in total biomass produced in homegarden and government institution compound

The difference may due to variance in preference to tree related livelihood strategies such as dependence on coffee based income and tree management system in rural area could be different from urban. Denu et al.(2016) reported that farmers preferred to some species such as Albizia gummifera related to their flat canopy cover and the perceived quality of coffee yield beneath, were in line with the abundance of tree species in the coffee plots. But in homegarden agroforestry, the highest (62.4\%) total biomass was produced by fruits tree such as Persea Americana (20.26\%), Mangifera indica (15.94\%), Eucalyptus spp. (13.16\%), Cordia Africana (13\%), and Gravilia robusta (7.38\%). Of these fruits such as Persea Americana and Mangifera indica accounted for about $36 \%$ of total biomass produced in homegarden. This indicated that fruit trees sequester huge amount carbon because of their dominance in homegarden agroforestry in urban area.

The total AGB carbon in three kebeles were higher than those reported in other area, for instance Kumar 
(2011) reported that aboveground standing stocks of $\mathrm{C}$ ranged from 16 to $36 \mathrm{Mg} \mathrm{ha}^{-1}$ in tropical home-gardens of Central Kerala, India whereas Mattsson et al. (2015) reported above-ground biomass carbon stock of $13 \mathrm{Mg}^{-1}$ in Sri Lanka. The study also indicated that the amount of stored(ranges from $0.34 \mathrm{Mgha}^{-1}$ to $26.61 \mathrm{Mgha}^{-1}$ ) is higher than that reported by Nair et al. (2010), which indicated the available estimates of carbon stored in agroforestry range from 0.3 to $15 \mathrm{Mg} \mathrm{C} \mathrm{ha}^{-1}$ in above ground. But the result showed lesser amount of carbon than reported in homegardens in Indonesia, which stored much higher to 55.8 to $162.7 \mathrm{Mg} \mathrm{C}^{-1}$ (Roshetko et al., 2002). However, majority of studies in homegarden estimated carbon stored in the soil which are important storage of carbon. Despite of these, the result indicated that homegarden of Jimma City contributed important contribution to $\mathrm{CO}_{2}$ mitigation through storage of carbon in their ABG and BGB.

\section{Conclusion and Recommendation}

Homegarden and government institutions in Jimma City are found to be an important refuge for native and endemic species of woody biodiversity and provide huge contribution for climate change mitigation through sequestration of $\mathrm{CO}_{2}$. Homegarden maintaining a quite a very good number of native plants spices that are deteriorating or facing a risk of disappearance in the natural habitat. However, few exotic (both fruit and tree) species are the dominant and substitute native species in homegardens and government institution compound have adversely affects plant diversity in Jimma City. Despite of these, all woody species in both systems are important in sequestering huge carbon dioxides.

In conclusion, urban homegardens in Jimma city have unleashed potential and a good future prospect for biodiversity conservation and climate change mitigation. To successfully realize the potential of urban vegetation in general and homegarden in specific requires awareness to decision makers and public and support to homegarden owners in terms of technical knowhow and access to and choice of appropriate planting species is desired. Besides, enriching with species socio-economically and environmentally multipurpose functions is important. Furthermore, urban land use/ development plan need to give much consider to native species as possible to maintain so as to create biodiversity-friendly gardens

\section{Reference}

Akinnifesi, F.K., Sileshi, G.W., Ajayi, O.C.,Akinnifesi, A.I., de Moura, E.G. and Linhares, I.R. (2010), Biodiversity of the urban homegrdens of Săo Luis City, Northeastern Brazil. Urban Ecosyst 13, 129-146

Atangana, A., Khasa D., Chang S. and Degrande, A. (2014), Phytoremediation in Tropical Agroforestry. Pp. 343351.

Axel, D. Jens, S. and Annette, F. (2011), Impact of tropical land use change on soil organic carbon stocks - a metaanalysis. Global Change Biology 17 (4), 1658-1670

Bajigo, A., Tadesse, M., Moges, Y. and Anjulo, A. (2015), Estimation of Carbon Stored in Agroforestry Practices in Gununo Watershed, Wolayitta Zone, Ethiopia. J Ecosys Ecograph 5, 157.

Brown, S. (1997). Estimating biomass and biomass change of tropical forests: a primer. FAO Forestry paper 134, Rome, $55 \mathrm{p}$.

Cavalcanti, E. A.H., Larraza 'bal, M .(2004), Macrozoopla ^ncton da zona econo ^mica exclusiva do nordeste do brasil (segunda expedic ,a o oceanogra 'fica-REVIZEE/NE II) com e ^nfase em Copepoda (Crustacea). Revista Brasileira de Zoologia 21(3), 467-475

Chalachew, A., Gudina L. and Debela, H.(2015), Analysis of land use/cover dynamics in Jimma city, Southwest Ethiopia: an application of satellite remote sensing. Ethiop.J.Appl.Sci. Technol 6 (2), 24-34.

Chave, J. R. Condit S., Lao, J. P., Caspersen, R., Foster, B. and Hubbell, S. (2003). Spatial and temporal variation of biomass in a tropical forest: results from a large census plot in Panama. Journal of Ecology 91,240-252.

Chave, J., Réjou-Méchain, M., Búrquez, A., Chidumayo, E., Colgan, M., Delitti, W., Duque, A., Eid, T., Fearnside, P., Goodman, R.C., Henry, M., Martínez-Yrízar, A., Mugasha, W.A., Muller-Landau,H.C., Mencuccini, M., Nelson, B.W., Ngomanda, A., Nogueira, E.M., Ortiz-Malavassi, E., Pélissier, R., Ploton, P., Ryan, C.M., Saldarriaga, J.G., Vieilledent, G. (2014), Improved allometric models to estimate the aboveground biomass of tropical trees. Global Change Biology 20, 3177-3190.

Cochran, W.G.(1977), Sampling Techniques. 3rd ed. John Wiley \&Sons, New York.

Dearborn, D.C. and Kark, S. (2009), Motivations for Conserving Urban Biodiversity. Conservation Biology: 24(2), $432-440$

FAO. (2012). National Forest Monitoring and Assessment-Manual for integrated field data collection. Version 3.0. National Forest Monitoring and Assessment Working Paper NFMA 37/E. Rome.

Guiabao, E.G.(2016), Above-Ground Carbon Stock Assessment of Mango-Based Agroforestry in Bulbul, Rizal, Kalinga, Philippines. International Journal of Interdisciplinary Research and Innovations 4(2), 19-25.

Gupta, R. K., Kumar, V., Sharma, K.R.; Buttar, T.S.; Singh, G. and Mir. G. (2017). Carbon Sequestration Potential through Agroforestry: A Review. Int.J.Curr.Microbiol.App.Sci 6(8), 211-220.

Hangarge, L.M., Kulkarni, D.K., Gaikwad, V.B., Mahajan, D.M. and Chaudhari, N.(2012). Carbon Sequestration 
potential of tree species in Somjaichi Rai (Sacred grove) at Nandghur village, in Bhor region of Pune District, Maharashtra State, India. Ann Biol Res. 3(7):3426-3429.

Henry, M., Tittonell, P., Manlay, R.J., Bernoux, M., Albrecht, A. and Vanlauwe, B. (2009), Biodiversity, carbon stocks and sequestration potential in abovegroundbiomass in smallholder farming systems of western Kenya. Agriculture, Ecosystems and Environment 129, 238-252.

IPCC. (2007). Climate Change: Synthesis Report. Contribution of Working Groups I, II and III to the Fourth Assessment Report of the Intergovernmental Panel on Climate Change. IPCC, Geneva, Switzerland, 104 pp.

Jose, S. and Bardhan, S.(2012).,Agroforestry for biomass production and carbon sequestration: an overview. Agroforestry Systems 86(2), 105-111.

Kauffman, J.B. and Donato, D.C. (2012), Protocols for the measurement, monitoring and reporting of structure,biomass and carbon stocks in mangrove forests. Working Paper 86. CIFOR, Bogor, Indonesia.

Kent, M. and Coker, P.(1992), Vegetation Description and Analysis: A Practical Approach. CRC press, Boca Raton Ann Arbor and Belhaven press, London. 255pp.

Kumar, B. M. (2011), Species richness and aboveground carbon stocks in the homegardens of central Kerala, India. Agriculture, Ecosystems \& Environment 140(3-4), 430-440.

Kunhamu, T.K. (2013). Tropical homegardens. pp- 365-375. In: Raj, A.J. and Lal, S.B. (eds.). Agroforestry-Theory and Practice. Scientific publishers (India), Jodhpur.

MacDicken, K. (1997), A guide to monitoring carbon storage in forestry and agroforestry projects. Winrock International, Arlington, VA.

Martin, G.J. (1995). Ethnobotany: a methods manual. Chapman and Hall, London, p 268

Mattsson, E., Ostwald, M., Nissanka, S.P. and Pushpakumara, D.K. (2015), Quantification of carbon stock and tree diversity of homegardens in a dry zone area of Moneragala district, Sri Lanka. Agroforestry Systems 89(3), 435-445.

McDonnell, N.J. and Hahs, A.K. (2012). The opportunity and challenges of maintaining biodiversity in urban areas. The University of Melbourne.

Mckinney, M.L. (2002), Urbanization, Biodiversity, and Conservation. BioScience 52(10), 883-890.

Mengistu, F. and Alemayehu, M. (2017), Species assortment and biodiversity conservation in homegardens of Bahir Dar City, Ethiopia. Ethiopian Journal of Agricultural Sciences. 27(2), 31-48.

Montagnini, F. and Nair, P.K.R. (2004), Carbon sequestration: an underexploited environmental benefit of agroforestry systems. Agroforest Syst. 61, $281-295$.

Motuma, T, Zebene, A, Mulugeta, L and Erik, K. (2008). Woody species diversity in a changing landscape in the south-central highlands of Ethiopia. Agriculture, Ecosystems and Environment 128, 52-58.

Mueller-Dombois, D. and Ellenberg, D.(1974), Aims and methods of vegetation ecology. Wiley \& Sons, New york, NY.

Nair, P.K.R., Kumar, B.M. and Vimala D. N. (2009), Agroforestry as a strategy for carbon sequestration. J. Plant Nutr. Soil Sci. 172, 10-23.

Nair, PKR. (2012), Climate Change Mitigation: A Low-Hanging Fruit of Agroforestry. pp. 31-67. In: Nair, PKR and Garrity, D. (Eds.). Agroforestry - the Future of Global Land Use. Springer, Dordrecht.

Nair. P.K.R., Nair, V.D., Kumar, B.M., Showalter, J.M., (2010), Carbon sequestration in agroforestry systems. Adv Agron. 108, 237-307.

Patel, S., Bisen, N., Jain, K. K. and Rahangdale, C. P. (2017), International Journal of Bio-resource and Stress Management, 8(3), 418-423.

Patil, H.Y., Mutanal, S.M. and Swamy, K.R.(2016). Assessment of carbon sequestration potential in four different plantation species. African Journal of Agricultural Science and Technology 4(2), 596-600.

Pearson, T., Walker, S., and Brown, S. (2005). Sourcebook for land-use, land-use change and forestry projects. Winrock International and the Biocarbon fund of the Worldbank. $57 \mathrm{pp}$.

Perez, C.L.D. and Kanninen, M. (2003), Above ground biomass of Tectona grandis plantation in Costa Rico. Journal of Forest Science 15(1), 199-213.

Roshetko, M., Delaney, M., Hairiah, K. and Purnomosidhi, P. (2002), Carbon stocks in Indonesian homegarden systems: Can smallholder systems be targeted for increased carbon storage? Amer J Altern Agric 17, 125137.

Secretariat of the Convention on Biological Diversity.(2012), Cities and Biodiversity Outlook. Montreal, 64p.

Segura, M.; Kanninen, M. and Suarez, D. (2006), "Allometric models 'for estimating aboveground biomass of shade trees and coffee bushes grown together," Agroforestry Systems 68(2), 143-150.

Sejati, A.W., Buchori, I. and Rudiarto, I. (2018), February. The Impact of Urbanization to Forest Degradation in Metropolitan Semarang: A Preliminary Study. In IOP Conference Series: Earth and Environmental Science 123(1), p. 012011 IOP Publishing.

Sheikh, M.A., Kumar, M. and Bussmann R.W.(2009), Altitudinal variation in soil organic carbon stock in coniferous subtropical and broadleaf temperate forests in Garhwal Himalaya. Carbon Balance and 
Management 4:6.

Shikur, E.T. (2012), Challenges and problems of urban forest development in Addis Ababa, Ethiopia. Challenges and problems of urban forest development in Addis Ababa, Ethiopia. 1(7); 130-140.

Steffan-Dewenter. I., Kessler, M., Barkmann, J., Bos, M., Buchori, D., Erasmi, S. (2007). Tradeoffs between income, biodiversity, and ecosystem functioning during tropical rainforest conversion and agroforestry intensification. PNAS 104,4973-4978.

Suryawanshi, M. N., Patel, A. R., Kale, T. S. and Patil, P. R. (2014), Carbon sequestration potential of tree species in the environment of North Maharashtra University Campus, Jalgaon (MS) India. Bioscience Discovery $\mathbf{5}(2), 175-179$.

Tellström, S. (2014), Urban agroforestry: For developing ecosystem services in urban forests.

Thaman, R.R.; Elevitch, C.R. and Kennedy, J. 2006. Urban and Homegarden Agroforestry in the Pacific Islands: Current Status and Future Prospects. Pp. 25-41. .In: Kumar and Nair (eds), Tropical Homegardens A TimeTested Example of Sustainable Agroforestry.

Verchot, L.V., Van Noordwijk, M., Kandji, S., Tomich, T. Ong, C., Albrecht, A. (2007). Climate change: linking adaptation and mitigation through agroforestry. Mitigation and adaptation strategies for global change 12(5), 901-918. 